УДК 595.423 (477.6)

\author{
А. Д. Штірц, Ю. Л. Кульбачко, А. В. Нікітенко, О. О. Дідур \\ Донецький наиіональний університет \\ Дніпропетровський національний університет ім. Олеся Гончара
}

\title{
ЕКОЛОГІЧНА СТРУКТУРА УГРУПУВАНЬ ПАНЦИРНИХ КЛЩЩВ (ACARIFORMES, ORIBATEI) ДІЛЯНОК РЕКУЛЬТИВАЦÏ̈ м. ЖОВТІ ВОДИ ДНІПРОПЕТРОВСЬКОЇ ОБЛАСТІ
}

Вивчено таксономічний склад і екологічну структуру угрупувань панцирних кліщів із рекультивованих ділянок, розташованих на території м. Жовті Води. Штучні деревні насадження сприяють підвищенню чисельності орибатид порівняно 3 техногенною ділянкою без деревостану. Показано роль насаджень деревних рослин і підстилки на ділянках рекультивації у перерозподілі життсвих форм орибатид i зміні структури їх комплексів. Установлено позитивний вплив штучних лісових культурбіогеоценозів в умовах техногенних ландшафтів на різних стадіях технічної рекультивації на формування екологічної структури угрупувань панцирних кліщів.

\author{
А. Д. Штирц, Ю. Л. Кульбачко, А. В. Никитенко, О. А. Дидур \\ Донецкий национальный университет \\ Днепропетровский национальный университет им. Олеся Гончара
}

\section{ЭКОЛОГИЧЕСКАЯ СТРУКТУРА СООБЩЕСТВ ПАНЦИРНЫХ КЛЕЩЕЙ (ACARIFORMES, ORIBATEI) УЧАСТКОВ РЕКУЛЬТИВАЦИИ Г. ЖЕЛТЫЕ ВОДЫ ДНЕПРОПЕТРОВСКОЙ ОБЛАСТИ}

\begin{abstract}
Изучены таксономический состав и экологическая структура сообществ панцирных клещей из рекультивированных участков, расположенных на территории г. Желтые Воды. Искусственные древесные насаждения способствуют повышению численности орибатид по сравнению с техногенным участком без древостоя. Показана роль древесных насаждений и подстилки на участках рекультивации в перераспределении жизненных форм орибатид и изменении структуры их комплексов. Установлено положительное влияние искусственных лесных культурбиогеоценозов в условиях техногенных ландшафтов на разных стадиях технической рекультивации на формирование экологической структуры панцирных клещей.
\end{abstract}

\author{
A. D. Shtirts, Y. L. Kul'bachko, A. V. Nikitenko, O. A. Didur \\ Donetsk National University \\ Oles' Gonchar Dnipropetrovsk National University
}

\section{ECOLOGICAL STRUCTURE OF ORIBATEI ASSOCIATES (ACARIFORMES, ORIBATEI) IN RECULTIVATED TERRITORIES OF ZHOVTI VODY, DNIPROPETROVSK REGION}

Taxonomical composition and ecological structure of Oribatei associates in recultivated territories located near Zhovti Vody town are investigated. The artificial arboreal planting causes increase of oribatida number in comparison with recultivated areas without arbors. Planting of trees and presence of the leaf litter promote to redistribution of oribatida life-form and change of structure in their complexes. The positive 
influence of artificial forest ecosystems in technogenic landscapes of different stages of technical remediation on forming of Oribatei ecological structure is shown.

\section{Вступ}

Панцирні кліщі - одна 3 найбільших груп кліщів, які у світовій фауні представлені понад 7000 видів, об'єднаними в 177 родин. Орибатиди належать до піонерних угрупувань безхребетних тварин, спроможних існувати в найжорсткіших умовах, там, де інші представники грунтових тварин не знаходять для себе сприятливих умов існування [2; 8]. Дослідження фауни, біотопічного розподілу, вертикальних міграцій у грунтовому профілі, сезонної динаміки чисельності панцирних кліщів південного сходу України розпочаті кафедрою зоології Донецького національного університету 3 1971 р. і проводяться беззупинно до цього часу. Зараз бібліографія, присвячена орибатидам регіону, нараховує понад 200 джерел. Збільшений інтерес до вивчення структурно-функціональної характеристики цієї групи тварин сприяв проведенню екологофауністичних та біоіндикаційних досліджень $[24 ; 25 ; 27 ; 28]$. Вони проводились не тільки в природних і штучних біогеоценозах [22], а й у техногенних ландшафтах. У рамках цього напряму досліджували шахтні відвали й рекультивовані терикони, промислові відвали підприємств, промислові площі заводських і шахтних територій, шламонакопичувачів, очисні споруди тощо [11-20; 23].

Узагальнювальною роботою $з$ фауни орибатид техногенних територій, проведеною у 1980-ті роки, слід вважати монографію М. М. Ярошенка [14], у якій подається докладний аналіз видового складу, сезонної динаміки чисельності, вказуються домінантні види. Характерною рисою техногенних біотопів $є$ збіднення видового складу орибатид. У фауні переважають, в основному, еврибіонтні види, при цьому спостерігається висока чисельність домінантних видів. Доведено, що орибатиди належать до піонерного угрупування мікроартропод, що заселяють промислові відвали й шахтні терикони вже в перші роки після закінчення відсипання. Вказується й на той факт, що основу комплексів орибатид породних відвалів і шламонакопичувачів становлять місцеві види, що мігрують на відвали з прилеглих ділянок.

У 1999 р. опубліковано монографію М. М. Ярошенка «Почвенные зооценозы промышленных экосистем Донбасса» [21], в якій підведені підсумки багаторічних досліджень грунтових зооценозів Донбасу, проведених на промислових відвалах, шахтних териконах, металургійних заводах, міських очисних спорудах тощо. Тут наведено видовий склад орибатид, характер сезонної динаміки чисельності та біотопічного розподілу різних безхребетних (панцирних, акароїдних і гамазових кліщів, колембол) у промислових екосистемах досліджуваного регіону. Науковий інтерес до цієї групи тварин також зумовлений іiі функціональною роллю в біогеоценозах. Активно живлячись у підстилці та мінеральних горизонтах грунту, орибатиди сприяють збагаченню органічною речовиною та продуктами iii розкладу глибоких шарів грунту [10].

Характер вертикального розподілу, кількісне співвідношення життєвих форм кліщів досить специфічне для різних типів грунтів. Тому мета цієї роботи - з'ясувати екологічну структуру угрупувань панцирних кліщів на рекультивованих територіях.

\section{Матеріал і методи досліджень}

Матеріал зібраний у 2008 р. на ділянках лісової рекультивації м. Жовті Води (Дніпропетровська обл.). Досліджували видовий склад і екологічну структуру угрупувань панцирних кліщів. Відбір проб здійснювали з трьох ділянок.

1. Штучні насадження робінії псевдоакації (Robinia pseudoacacia L.). Висота дерев - до 5-6 м. Ширина міжрядь - 2,5-3 м. Зімкнутість крон - 0,3. Слабкорозвинений 
покрив підстилки з листочків псевдоакації та злаків потужністю $0,5-1,0$ см. Трав'яний покрив представлений тонконого-пирійною асоціацією.

2. Штучні насадження маслинки вузьколистої (Elaeagnus angustifolia L.). Висота дерев - до 4 м. Ширина міжрядь - 4-5 м. Підстилка відсутня. Трав'яний ярус сформований рудеральною рослинністю з переважанням пирію повзучого.

3. Ділянка без деревостану з рудерально-степовою рослинністю з домінуванням пирію повзучого.

Збір грунтових проб і вигонку кліщів проводили за загальноприйнятою методикою О. М. Буланової-Захваткіної [2]. Збір проб виконували у 6-разовій повторності, об'ємом 250 cм³ $^{3}$. Вигонку кліщів здійснювали за допомогою термоеклекторів Тульгрена - Берлезе. Тварин фіксували у 70 \% розчині етилового спирту. Визначення тварин проводили в лабораторії акарології кафедри зоології Донецького національного університету.

Видовий склад установлювали за визначниками «Определитель обитающих в почве клещей. Sarcoptiformes» [6], «Определитель цератозетоидных клещей Украины» [7], за монографією Г. Д. Сергієнко «Фауна Украины. Низшие орибатиды» [9], а також за статтями 3 першоописами видів.

Для порівняння кількості кліщів у різних біотопах використовували шкалу домінування Г. Енгельмана [26]. Адаптивні типи (життєві форми) панцирних кліщів наведено відповідно до робіт Д. А. Криволуцького [3], Д. А. Криволуцького та ін. [8]. Для оцінки екологічного різноманіття панцирних кліщів досліджуваних ділянок використано загальноприйняті індекси Шеннона, Пієлу, полідомінантності, Маргалефа та Бергера - Паркера $[1 ; 5]$. Кластерний аналіз із побудовою дендрограми подібності проведено у пакеті прикладних програм Statistica 6.0. За міру відстані обрано евклідову відстань за методом Варда.

\section{Результати та їх обговорення}

У ході досліджень з проб вилучено 405 екз. дорослих панцирних кліщів, що належать до 19 видів (табл. 1). Аналізуючи середню щільність та видове багатство панцирних кліщів, слід відзначити достатньо високий показник щільності для порушених техногенних біогеоценозів. Мінімум щільності відмічено на ділянці без деревостану (7 600 екз./ м $^{2}$ ), а максимум - на ділянці з Robinia pseudoacacia $(12066$ екз./м²). Видове багатство невисоке, варіює від 9 видів на ділянці без деревостану до 12 - на ділянках із маслинкою вузьколистою та робінією (рис. 1). У цілому на ділянках без деревостану обидва показники мінімальні порівняно з ділянками штучних деревних насаджень.

Для одержання уявлення про стратифікаційну структуру угрупувань панцирних кліщів застосовано кластерний аналіз - один із методів статистичного багатомірного аналізу, сутність якого полягає в ієрархічній класифікації об'єктів. Нами виконано кластеризацію вибірок орибатид на основі матриці щільності та показників домінування. Кластерний аналіз підтверджує тенденцію подібності угрупувань орибатид у штучних насадженнях робінії й маслинки та відмінність від них угрупування на ділянці без деревостану (рис. 2).

В екологічних дослідженнях досить часто для оцінки біологічного різноманіття використовують різні індекси. Їх запропоновано понад 40. Із них найпоширеніші показники Шеннона, Пієлу, Сімпсона, Маргалефа тощо.

Інформаційна ентропія Шеннона показує кількість невизначеності (різноманіття) у гетерогенній системі. Зрушення цього показника у бік максимального значення свідчить про більш однорідний (різноманітніший) елементний склад об'єкта. На відміну від 
індексу Шеннона індекс Пієлу вільний від кількості елементів у системі; інші його назви відносна ентропія або індекс вирівняності. Він дозволяє коректно порівнювати системи, які складаються з різної кількості елементів, що визначають величину ентропії [4]. Величина відносної ентропії коливається в межах від 0 до 1, набираючи мінімальних значень при зниженні однорідності розподілу елементів і максимальних - у разі збільшення гетерогенності розподілу елементів системи. Як видно 3 таблиці 2, найоднорідніша чисельність панцирних кліщів із насаджень із маслинки (індекс Пієлу дорівнює 0,82), а найменш однорідна - на ділянці у насадженнях робінії (індекс Пієлу - 0,74).

Видовий склад, чисельність, індекси домінування та життєві форми

Таблиия 1 панцирних кліщів рекультивованих ділянок

\begin{tabular}{|c|c|c|c|c|}
\hline Вид & $\begin{array}{l}\text { Життєва } \\
\text { форма }\end{array}$ & $\begin{array}{c}\text { Ділянка } \\
\text { без насаджень } \\
\text { (грунт, 0-10 см) }\end{array}$ & $\begin{array}{c}\text { Насадження } \\
\text { маслинки } \\
\text { (підстилка }+ \\
\text { грунт, } 0-10 \text { см) }\end{array}$ & $\begin{array}{c}\text { Насадження } \\
\text { робінії } \\
\text { (підстилка }+ \\
\text { грунт, } 0-10 \mathrm{~cm} \text { ) }\end{array}$ \\
\hline Ramusella mihelcici (Perez-Inigo, 1965) & МДГС & $6 / \mathrm{SD}(10,53)$ & $38 / \mathrm{D}(22,75)$ & $38 / \mathrm{D}(20,99)$ \\
\hline $\begin{array}{l}\text { Lauroppia neerlandica } \\
\text { (Oudemans, 1900) }\end{array}$ & МДГС & $2 / \mathrm{R}(3,51)$ & 3/R $(1,80)$ & 0 \\
\hline Medioppia obsoleta (Paoli, 1908) & МДГС & 0 & $9 / \mathrm{SD}(5,39)$ & 0 \\
\hline $\begin{array}{l}\text { Epilohmannia cylindrica cylindrica } \\
\text { (Berlese, 1904) }\end{array}$ & $\Gamma \Phi$ & $8 / \mathrm{D}(14,04)$ & $14 / \mathrm{SD}(8,38)$ & $1 / \mathrm{SR}(0,55)$ \\
\hline $\begin{array}{l}\text { Rhysotritia ardua affinis } \\
\text { Sergienko, } 1989\end{array}$ & МТП & 1/R (1,75) & 1/SR $(0,60)$ & 0 \\
\hline $\begin{array}{l}\text { Hypochthonius luteus luteus } \\
\text { Oudemans, } 1917\end{array}$ & НФ (п) & 0 & $1 / \mathrm{SR}(0,60)$ & 0 \\
\hline Punctoribates liber Pavlitshenko, 1991 & НФ (в) & $18 / \mathrm{D}(31,58)$ & 0 & $7 / \mathrm{R}(3,87)$ \\
\hline Protoribates vastus (Mihelčič, 1955) & НФ (в) & $17 / \mathrm{D}(29,82)$ & $22 / \mathrm{D}(13,17)$ & $5 / \mathrm{R}(2,76)$ \\
\hline Tectocepheus velatus (Michael, 1880) & НФ (в) & $3 / \mathrm{SD}(5,26)$ & $33 / \mathrm{D} /(19,76)$ & $46 / \mathrm{D}(25,41)$ \\
\hline $\begin{array}{l}\text { Protoribates monodactylus } \\
\text { (Haller, 1884) }\end{array}$ & НФ (в) & $1 / \mathrm{R}(1,75)$ & 0 & 0 \\
\hline $\begin{array}{l}\text { Scheloribates laevigatus } \\
\text { (C. L. Koch, 1835) }\end{array}$ & НФ (в) & 0 & 23/D $(13,77)$ & 0 \\
\hline $\begin{array}{l}\text { Ceratozetes minutissimus affinis } \\
\text { Willmann, } 1951\end{array}$ & НФ (в) & 0 & 2/SR $(1,20)$ & 0 \\
\hline Scutovertex sculptus Michael, 1879 & НФ (в) & 0 & $1 / \mathrm{SR}(0,60)$ & $1 / \mathrm{SR}(0,55)$ \\
\hline Tectoribates ornatus (Schuster, 1958) & НФ (в) & 0 & 0 & 2/SR $(1,10)$ \\
\hline Zygoribatula frisiae (Oudemans, 1900) & НФ (в) & 0 & 0 & $10 / \mathrm{SD}(5,52)$ \\
\hline $\begin{array}{l}\text { Metabelba pulverulenta } \\
\text { (C. L. Koch, 1839) }\end{array}$ & МПГ & 0 & 20/SD $(11,98)$ & $44 / \mathrm{D}(24,31)$ \\
\hline Pilogalumna allifera (Oudemans, 1915) & МПГ & 1/R $(1,75)$ & 0 & $25 / \mathrm{D}(13,81)$ \\
\hline Galumna dimorpha Krivolutzkaja, 1952 & МПГ & 0 & 0 & $1 / \mathrm{SR}(0,55)$ \\
\hline $\begin{array}{l}\text { Gymnodamaeus bicostatus } \\
\text { (C. L. Koch, 1835) }\end{array}$ & МПГ & 0 & 0 & $1 / \mathrm{SR}(0,55)$ \\
\hline \multicolumn{2}{|l|}{ Чисельність, екз. } & 57 & 167 & 181 \\
\hline \multicolumn{2}{|l|}{ Кількість видів } & 9 & 12 & 12 \\
\hline \multicolumn{2}{|l|}{ Щільність, екз./м² } & 7600 & 11133 & 12066 \\
\hline
\end{tabular}

Примітки: життєві форми: МПГ - мешканці поверхні грунту, МТП - мешканці товщі підстилки, МДГС - мешканці дрібних грунтових свердловин, ГФ - глибокогрунтові форми, НФ (п) - первинно неспеціалізовані форми, НФ (в) - вторинно неспеціалізовані форми; у чисельнику - чисельність панцирних кліщів (екз.), у знаменнику домінування за шкалою Г. Енгельмана (\%); характеристики домінування: E - еудомінант (понад 40 \%), D - домінант (12,5-39,9\%), SD - субдомінант (4,0-12,4\%), R - рецедент (1,3-3,9\%), SR - субрецедент $(<1,3 \%)$.

Структуру домінування можна характеризувати індексами полідомінантності (заснований на індексі Сімпсона) та Бергера - Паркера. Якщо індекс полідомінантності 104 
інтегрально характеризує всю сукупність, то індекс Бергера - Паркера дає уявлення тільки про частку лише одного домінантного виду 3 найбільшою чисельністю в угрупуванні. Максимальне значення цих показників одержано для угрупувань панцирних кліщів із насаджень маслинки. Це свідчить про зменшення в них частки домінантних видів і збігається з індексом Пієлу та Шеннона. Частка домінантних видів кліщів на ділянці без деревних насаджень зростає.

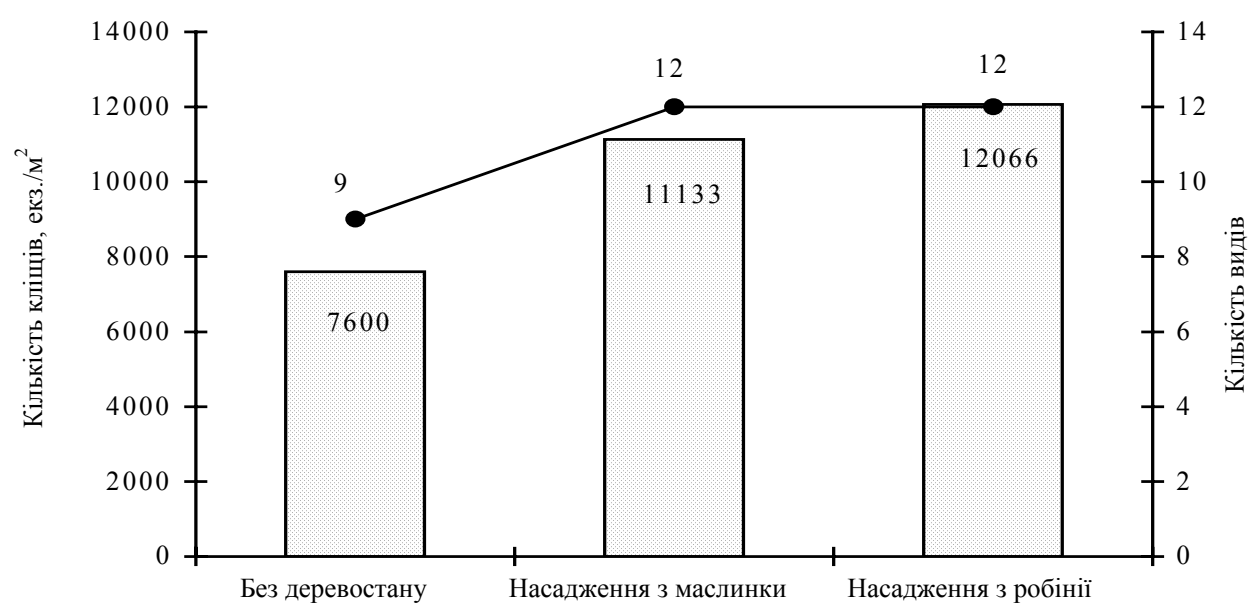

Рис. 1. Середня щільність населення та видове багатство панцирних кліщів ділянок рекультивації м. Жовті Води

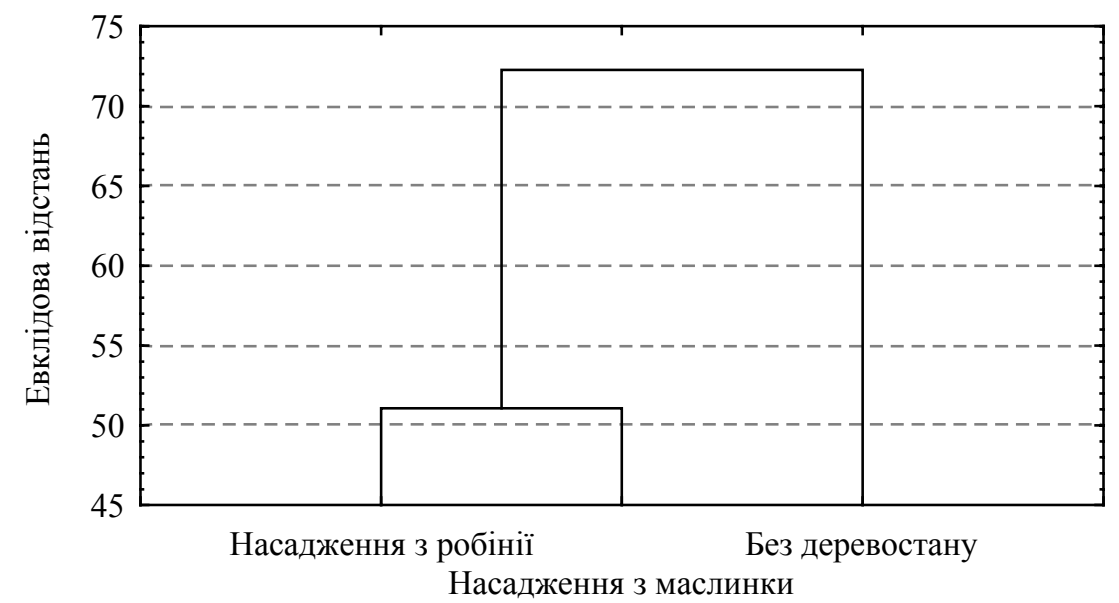

Рис. 2. Результати статистичної кластеризації угрупувань панцирних кліщів ділянок рекультивації м. Жовті Води

Таблиия 2

Індекси різноманіття угрупувань панцирних кліщів ділянок рекультивації м. Жовті Води

\begin{tabular}{|l|c|c|c|}
\hline \multirow{2}{*}{ Індекс } & \multicolumn{3}{|c|}{ Ділянки рекультивації } \\
\cline { 2 - 4 } & без деревостану & насадження маслинки & насадження робінії \\
\hline Шеннона & 1,72 & 2,03 & 1,84 \\
\hline Пієлу & 0,78 & 0,82 & 0,74 \\
\hline Полідомінантності & 4,75 & 6,81 & 5,32 \\
\hline Бергера - Паркера & 3,17 & 4,39 & 3,94 \\
\hline Маргалефа & 1,98 & 2,15 & 2,12 \\
\hline
\end{tabular}

Примітка: індекс Бергера - Паркера розрахований як зворотна функція. 
Для з'ясування видового багатства угрупувань кліщів застосовано індекс Маргалефа. Його більші значення характерні для угрупувань кліщів із насаджень маслинки та робінії $(2,15$ і 2,12 відповідно), а найменше - для ділянки без деревостану $(1,98)$. На останній ділянці зустрічається найменша кількість видів кліщів і спостерігається їх найменша чисельність.

Аналізуючи структуру домінування панцирних кліщів досліджених ділянок, слід відзначити, що на ділянці без деревостану відмічено 3 домінанти: Punctoribates liber (31,6 \%), Protoribates vastus (29,8 \%), Epilohmania cylindrica cylindrica (14,0\%) (див. табл. 1). До субдомінантів віднесено 2 види, до рецедентів - 4 (8,76 \%). Слід також відзначити відсутність субрецедентів на даній ділянці (рис. 3).

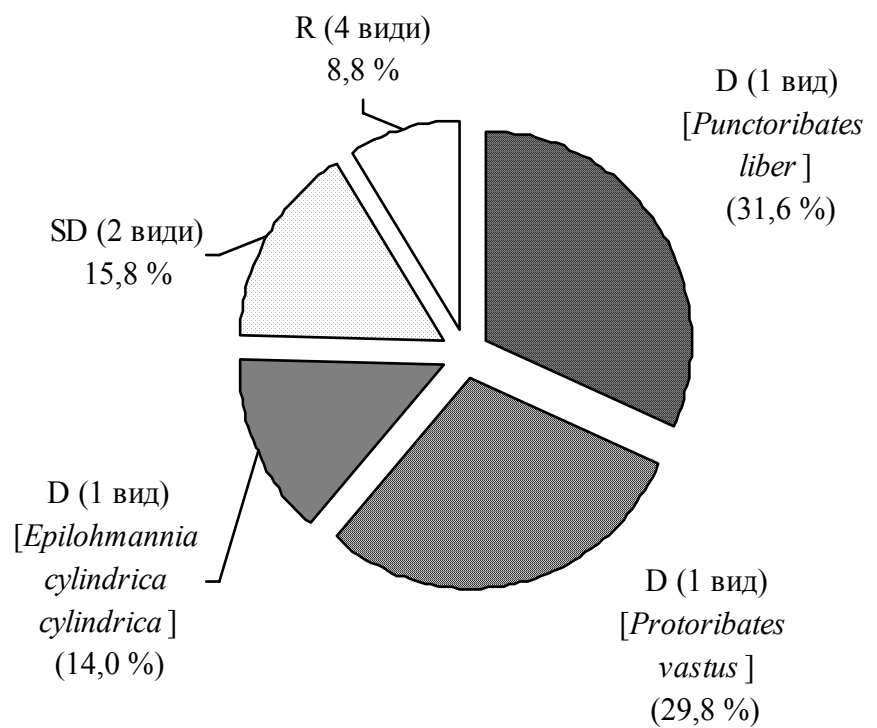

Рис. 3. Структура домінування угрупування панцирних кліщів ділянки рекультивації без деревостану м. Жовті Води

На ділянці $з$ маслинкою вузьколистою відмічено 4 домінантні види: Tectocepheus velatus (19,8 \%), Protoribates vastus (13,2 \%), Ramusella mihelcici (22,8 \%), Scheloribates laevigatus (13,8 \%) (табл. 1). До субдомінантів віднесено 3 види $(25,8 \%)$, до субрецедентів - 4 види (3,0 \%), до рецедентів - 1 вид (1,8 \%) (рис. 4). Порівняно 3 попередньою ділянкою змінився характер розподілу домінантів: залишається лише Protoribates vastus і частка цього виду знижується більш ніж удвічі (з 29,8 до 13,1 \%). 3'являються нові домінанти: Tectocepheus velatus (19,8\%), Ramusella mihelcici (22,8 \%), Scheloribates laevigatus (13,8 \%). Punctoribates liber на даній ділянці не відзначений. Epilohmania cylindrica cylindrica переходить у ранг субдомінантів (див. табл. 1).

На ділянці з робінією також відмічаються 4 домінантні види: Ramusella mihelcici (21,0 \%), Pilogalumna allifera (13,8 \%), Tectocepheus velatus (25,4 \%), Metabelba pulverulenta (24,3\%). До субдомінантів належить 1 вид (5,6 \%), до субрецедентів 5 видів (3,3 \%) і до рецедентів - 2 види (6,6 \%) (рис. 5). Порівняно 3 попередньою ділянкою частка двох домінантних видів (Tectocepheus velatus та Ramusella mihelcici) не змінюється. З'являються два нові домінанти: Metabelba pulverulenta (24,3 \%) і Pilogalumna allifera (13,8 \%). Домінант двох попередніх ділянок Protoribates vastus переходить у ранг рецедентів, а домінантний Scheloribates laevigatus виявлений лише на ділянці з маслинкою вузьколистою. 


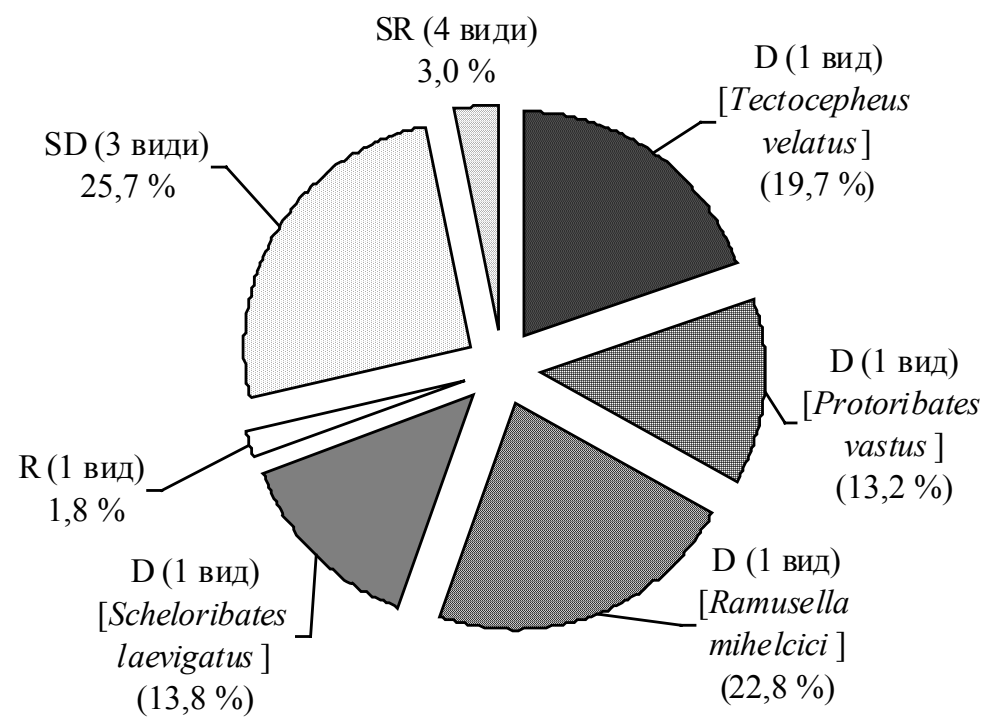

Рис. 4. Структура домінування угрупування панцирних кліщів ділянки рекультивації з маслинкою

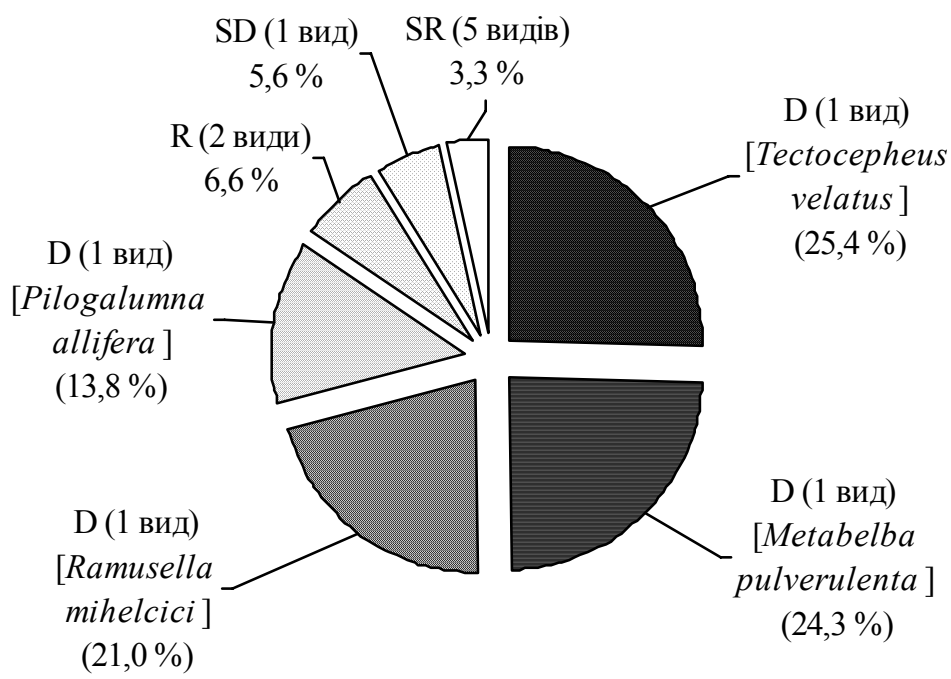

Рис. 5. Структура домінування угрупування панцирних кліщів ділянки рекультивації з робінією

Аналізуючи три угрупування кліщів, можна відмітити високу подібність їх структури на ділянці 3 деревостаном (маслинкою вузьколистою та робінією) та відмінність від них структури угрупувань орибатид на ділянці без деревостану.

Наявність деревних порід і листяного опаду зумовлює більше різноманіття видів, більш вирівняну структуру домінування, наявність в угрупуванні субрецедентних видів. Причому, якщо на ділянці 3 маслинкою вузьколистою переважають неспеціалізовані форми (Protoribates vastus, Scheloribates laevigatus, Tectocepheus velatus), а також мешканці дрібних грунтових свердловин (Ramusella mihelcici), то на ділянці 3 робінією - мешканці поверхні грунту (Pilogalumna allifera та Metabelba pulverulenta), 
що в першу чергу можна пов'язати з наявністю листової підстилки, а також мешканці дрібних грунтових свердловин (Ramusella mihelcici) i неспеціалізовані форми (Tectocepheus velatus). На ділянці без деревостану домінують неспеціалізовані (Punctoribates liber, Protoribates vastus) та глибокогрунтові форми (Epilohmania cylindrica cylindrica).

Аналізуючи співвідношення життєвих форм (рис. 6), слід зазначити, що основу комплексу орибатид досліджуваних ділянок складають представники вторинно неспеціалізованих форм, частка яких варіює від 39,2 \% (на ділянці з робінією) до 68,4 \% (на ділянці без деревостану). Менший внесок роблять мешканці дрібних грунтових свердловин, поверхні грунту та глибокогрунтові форми. Рідко зустрічаються мешканці товщі підстилки та Protoribates vastus. На ділянці без деревостану основу комплексу складають вторинно неспеціалізовані форми; мешканці дрібних грунтових свердловин і глибокогрунтові форми розподілені порівну (по 14,5 \%), так само як і представники двох інших груп, що відіграють значно меншу роль: мешканці товщі підстилки та первинно неспеціалізовані форми (по 1,75 \%).

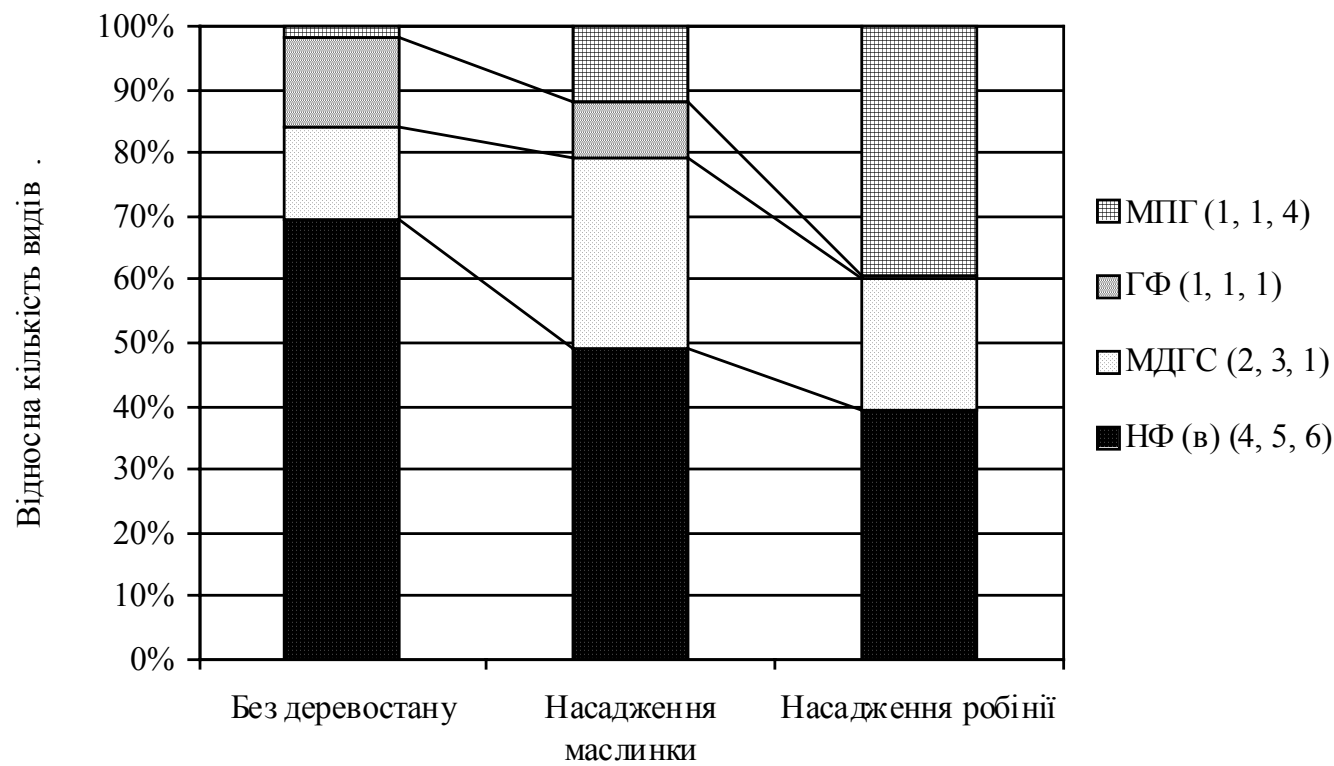

Рис. 6. Співвідношення життєвих форм панцирних кліщів ділянок рекультивації:

МПГ - мешканці поверхні грунту, МДГС - мешканці дрібних грунтових свердловин, ГФ - глибокогрунтові форми, НФ (в) - вторинно неспеціалізовані форми; у дужках - кількість видів, що належать до певної життєвої форми; первинно неспеціалізовані форми представлені тільки у насадженні з маслинки (їх частка дуже мала), частка мешканців товщі підстилки серед інших форм також мала на всіх ділянках, тому на рисунку ці обидві життєві форми не відзначені

На ділянці рекультивації з маслинкою вузьколистою знижується частка вторинно неспеціалізованих форм за рахунок збільшення мешканців дрібних грунтових свердловин та поверхні грунту. На ділянці з робінією частка вторинно неспеціалізованих форм знижується ще більше та вирівнюється з мешканцями поверхні грунту. Понад 20 \% у даному випадку припадає на мешканців дрібних грунтових свердловин, а інші життєві форми практично відсутні (див. рис. 6). 
Таким чином, насадження деревних рослин і поява листяного опаду на ділянках рекультивації сприяють перерозподілу співвідношення життєвих форм орибатид і зміні (вирівнянню) структури їх комплексів.

\section{Висновки}

Середня щільність населення орибатид на досліджуваних пробних ділянках має достатньо високі значення. Штучні деревні насадження сприяють підвищенню чисельності орибатид у 1,6 раза порівняно з техногенною ділянкою без деревостану. На рекультивованих ділянках виявлено невисоке видове багатство панцирних кліщів. Кількість їх видів варіює від 9 на ділянці без деревостану до 12 на ділянках із штучними деревними насадженнями.

Насадження деревних рослин і поява листяного опаду на ділянках рекультивації сприяють перерозподілу співвідношення життєвих форм орибатид і зміні (вирівнянню) структури їх комплексів. Основу комплексу орибатид усіх досліджуваних ділянок складають представники вторинно неспеціалізованих форм. Менший внесок до загальної структури розподілу життєвих форм вносять мешканці дрібних грунтових свердловин, поверхні грунту та глибокогрунтові форми. Але вже поряд із цим зустрічаються мешканці товщі підстилки та первинно неспеціалізовані форми.

Формування більш збалансованої екологічної структури угрупування панцирних кліщів під деревними насадженнями культурбіогеоценозів $є$ індикатором успішності проведеної рекультивації досліджуваного техногенного ландшафту м. Жовті Води. Але склад i екологічна структура населення панцирних кліщів рекультивованих ділянок ще далекі від такої у непорушених біогеоценозах, i для відновлення нормальної структури угрупувань орибатид повинен минути певний час.

\section{Бібліографічні посилання}

1. Аналіз структури популяцій / С. В. Шебанін, С. І. Мельник, С. С. Крамаренко, В. М. Ганганов. - Миколаїв : МДАУ, 2008. - 240 с.

2. Буланова-Захваткина Е. М. Панцирные клещи - орибатиды. - М. : Высш. шк., 1967. - 254 с.

3. Криволуцкий Д. А. Морфоэкологические типы панцирных клещей (Acariformes, Oribatei) // Зоол. журн. - 1965. - Т. 44, вып. 8. - С. 1176-1189.

4. Леонтюк А. С. Информационный анализ в морфологических исследованиях / А. С. Леонтюк, Л. А. Леонтюк, А. И. Сыкало. - Минск : Наука и техника, 1981. - 160 с.

5. Мэгарран Э. Экологическое разнообразие и способы его измерения: Пер. с англ. - М. : Мир, 1992. $-184 \mathrm{c}$.

6. Определитель обитающих в почве клещей (Sarcoptiformes) / Е. М. Буланова-Захваткина, Б. А. Вайнштейн, В. И. Волгин и др. / Под ред. М. С. Гилярова. - М. : Наука, 1975. - 491 с.

7. Определитель цератозетоидных клещей (Oribatei, Ceratozetoidea) Украины / П. Г. Павличенко. - К. : Ин-т зоологии им. И. И. Шмальгаузена, 1994. - 143 с.

8. Панцирные клещи: морфология, развитие, филогения, экология, методы, исследования, характеристика модельного вида Nothrus palustris C. L. Koch, 1839 / Д. А. Криволуцкий, Ф. Лебрен, М. Кунст и др. / Под ред. Д. А. Криволуцкого. - М. : Наука, 1995. - 224 с.

9. Сергиенко Г. Д. Фауна Украины. Низшие орибатиды. - К. : Наук. думка, 1994. - Т. 25, вып. 21. -203 с.

10. Стриганова Б. Р. Питание почвенных сапрофагов. - М. : Наука, 1980. - 244 с.

11. Штирц А. Д. Распределение панцирных клещей по профилю техногенной катены (на примере шлакоотвала Донецкого металлургического завода) / А. Д. Штирц, И. И. Богатиков // Проблемы экологии и охраны природы техногенного региона. - Донецк : ДонНУ, 2005. - С. 108-118.

12. Ярошенко Н. Н. К фауне орибатид озелененных шахтных терриконов. - Донецк : Донецкий ун-т, 1982. - 6 с. - Деп. в ВИНИТИ 12.08.1982, № 4452. 
13. Ярошенко Н. Н. К фауне орибатидных клещей техногенных ландшафтов Донбасса // Тез. докл. V Всесоюзн. совещ. - Фрунзе, 1985. - С. 337.

14. Ярошенко Н. Н. Динамика орибатидных клещей и прочих беспозвоночных животных промышленных ландшафтов Донбасса. - Донецк : Донецкий ун-т, 1987. - 330 с. - Деп. в УкрНИИНТИ 02.04.1987, № 109.

15. Ярошенко Н. Н. Биотопическое и сезонно-вертикальное распределение орибатидных клещей (Acariformes, Oribatei) в условиях Ворошиловградской области. - Донецк : Донецкий ун-т, 1988. - 155 с. - Деп. в УкрНИИНТИ 10.08.1988, № 1880.

16. Ярошенко Н. Н. Динамика почвенного зооценоза рекультивированных ландшафтов Донбасса // Экологические проблемы охраны живой природы. Тез. докл. Всесоюзн. конф. - М., 1990. Ч. 2. - C. 101-102.

17. Ярошенко Н. Н. Экология орибатидных клещей (Acariformes, Oribatei) естественных и техногенных ландшафтов Украины: Автореф. дисс. ... д-ра биол. наук: 03.00.16. - М., 1992. - 45 с.

18. Ярошенко Н. Н. Распространение индикаторного вида Passalozetes intermedius Mih. в техногенных биоценозах Донбасса // Вестн. Днепропетр. ун-та. Биология. Экология. - 1993. Вып. 1. - С. 81-82.

19. Ярошенко Н. Н. Орибатидные клещи (Acariformes, Oribatei) промышленных экосистем Донбасса / Н. Н. Ярошенко, А. Д. Штирц // Вісник Донецького ун-ту, сер. А.: Природн. науки. 1997. - Вип. 1. - С. 184-189.

20. Ярошенко Н. Н. Орибатидные клещи промышленных экосистем Донбасса // Тез. доп. V з’їзду Укр. ентомол. т-ва. - К., 1998. - С. 188-189.

21. Ярошенко Н. Н. Почвенные зооценозы промышленных экосистем Донбасса. - Донецк : ДонГУ, 1999. - $294 \mathrm{c}$.

22. Ярошенко Н. Н. Орибатидные клещи (Acariformes, Oribatei) естественных экосистем Украины. - Донецк : ДонНУ, 2000. - 313 с.

23. Ярошенко Н. Н. Педобионты земельного отвода Васильевского участка Андреевского месторождения огнеупорных глин (Донецкая область) // Вісник Донецького ун-ту. Сер. А: Природничі науки. - 2006. - Вип. 1. - С. 334-340.

24. Spatial patterns and autocorrelation in the response of microarthropods to soil pollutants: The example of oribatid mites in an abandoned mining and smelting area / T. Caruso, M. Migliorini, C. Bucci, R. Bargagli // Environmental Pollution. - 2009. - Vol. 157, N 11. - P. 2939-2948.

25. Ecological risk assessment of organic waste amendments using the species sensitivity distribution from a soil organisms test battery / X. Domene, W. Ramírez, S. Mattana et al. // Environmental Pollution. - 2008. - Vol. 155, N 2. - P. 227-236.

26. Engelmann H. D. Zur Dominanzklassifizierung von Bodenartropoden // Pedobiologia. - 1978. Bd. 18, Hf. 5/6. - S. 378-380.

27. Identification of metal-responsive oribatid mites in a comparative survey of polluted soils / M. A. Khalil, T. K. S. Janssens, M. P. Berg, N. M. van Straalen // Pedobiologia. - 2009. - Vol. 52, N 3. - P. 207-221.

28. Reducing the dimensionality of soil microinvertebrate community datasets using Indicator Species Analysis: Implications for ecosystem monitoring and soil management / K. P. O’Neill, H. W. Godwin, A. E. Jiménez-Esquilín, J. P. Battigelli // Soil Biology and Biochemistry. - 2010. - Vol. 42, N 2. P. 145-154.

Надійшла до редколегії 14.05.2010 